$\begin{array}{ll}\text { Research Square } & \text { Preprints are preliminary reports that have not undergone peer review. } \\ \text { They should not be considered conclusive, used to inform clinical practice, } \\ \text { or referenced by the media as validated information. }\end{array}$

\title{
Tracking Recent DDT Contamination in a Northern New England Watershed: A Geosciences Approach
}

Amanda May ( $\square$ amanda.may1796@gmail.com )

Plymouth State University Department of Environmental Science and Policy https://orcid.org/0000-0002-4798-3767

Lisa Doner

Plymouth State University Department of Environmental Science and Policy

Jeremiah Duncan

Plymouth State University Department of Atmospheric Science and Chemistry

Stephen Hill

Plymouth State University

\section{Research Article}

Keywords: DDT, DDD, United States, New Hampshire

Posted Date: April 6th, 2021

DOI: https://doi.org/10.21203/rs.3.rs-373867/v1

License: (c) (i) This work is licensed under a Creative Commons Attribution 4.0 International License. Read Full License 


\section{Abstract}

The p,p' isomers of DDT, DDE, and DDD were analyzed in soils, sediments, and crayfish in the Squam Lake watershed in central New Hampshire (NH), U.S.A. Bennett Brook sources elevated levels of DDT residues to Squam Lake through sediment transport, likely due to legacy contamination from applications to an apple orchard surrounding the stream in the mid 1900s. Results reveal a point source located at a barn used during the orchard operation, which was burned down around 1967, with up to $723 \mu \mathrm{g} / \mathrm{kg}$ p,p' DDT and $721 \mu \mathrm{g} / \mathrm{kg} \mathrm{p,p'} \mathrm{DDE} \mathrm{in} \mathrm{the} \mathrm{soils.} \mathrm{Higher} \mathrm{DDT} \mathrm{than} \mathrm{DDE} \mathrm{in} \mathrm{soil} \mathrm{samples,} \mathrm{but} \mathrm{not} \mathrm{in} \mathrm{sediment} \mathrm{samples,}$ suggests persistence of the contaminant in watershed soils, and faster degradation once mobilized into Bennett Brook and Squam Lake. DDT residues in the lake sediments from 1951 to the present, reveal DDT has consistently been entering Squam Lake since usage began in the U.S. There are likely multiple sources that have contributed to the constant supply, including the orchard soils treated with DDT serving as a nonpoint source, the barn site, and DDT-laden soils vulnerable to erosion, including stream banks and logged or steeply sloped land. Detections of residues in the stream and lake sediments exceed certain sediment quality guidelines for the protection of aquatic life. Higher p,p' DDE levels in crayfish collected in the mouth of Bennett Brook versus crayfish collected in Squam Lake, distant from Bennett Brook, suggests that residues sourcing from this sub-watershed are entering the aquatic food chain at levels higher than other parts of the lake.

\section{Introduction}

DDT was banned in the United States (U.S.) in 1972, due to its adverse impacts on ecosystems and persistence in the environment (USEPA 1975). Despite the ban of DDT almost 50 years ago, DDT is still detected in biota, sediments, and soils throughout the world (Rissato et al. 2006, Andrews et al. 2009, Hu et al. 2010, Yang et al. 2013, Bettinetti et al. 2016, Kang et al. 2016, Feingold and Benoit 2018, Khuman et al. 2019, Das et al. 2020). In 2004 to 2005, 44\% of all resident loons died on Squam Lake, NH, followed by low reproductive successes (Vogel 2010). Tests of loon eggshells revealed elevated levels of DDT residues, along with other contaminants including PCBs, PFOS, PBDEs, dioxins and furans (Vogel 2010). Sediment samples collected in 2015 and 2016 from 14 tributary inlets to Squam Lake revealed elevated levels of DDT residues at the mouth of Bennett Brook (Vogel 2019).

Sediment transport is the leading mechanism for dispersal and also is a major sink for DDT residues (USDOI 1998, Yang et al. 2013). DDT is a non-polar pesticide that does not easily dissolve in water but readily sorbs to organic matter, clay and silts in soils and sediments by hydrophobic bonding (Boul 1995, Leatherman 1997, Wohl 2015). DDT often concentrates in the uppermost soil layers. which can be eroded by heavy rains and floods. Once transported to rivers and lakes, DDT is bioavailable to aquatic organisms. DDT readily dissolves, and is stored, in fatty tissues, resulting in bioaccumulation. Adverse impacts in piscivorous birds highest on the aquatic food chain include eggshell thinning, reproductive impairment, and low fledging success (Ames 1966, Nygård 1983, USDOI 1998).

DDT breaks down into DDE and DDD under aerobic and anaerobic conditions, respectively (Boul 1995, Quensen et al. 1998, Gao et al. 2013). Therefore, in the upper, aerobic layers of soils, DDE is the main residue, whereas in anoxic lake bottoms and wetlands, DDD is the main residue and the most easily microbially degraded (Pham et al. 1993, Boul 1995). DDT is composed of two isomers of about 85\% p,p' DDT and 15\% o,p' DDT (ATSDR 2002). The isomer p,p' DDT degrades into p,p' DDD and/or p,p' DDE, and o,p' DDT degrades into o,p' DDD and/or o,p' DDE (Ricking and Schwarzbauer 2012). The half-life of DDT is variable, generally 2 to 35 years depending on local environmental conditions (Nash and Woolson 1967, Lichtenstein et al. 1971, Dimond and Owen 1996, Leatherman 1997). The rate of degradation may vary continuously, often with faster rates immediately after application or introduction into the environment (Lichtenstein et al. 1971). The half-life in soil varies with soil type, organic carbon content, soil pH, temperature, susceptibility to volatilization, microbial activity, tilling, and flooding (Nash and Woolson 1967, Pham et al. 1993, Boul et al. 1994, Boul 1995, Dimond and Owen 1996, USDOI 1998). Since the ban of DDT in 1972, the ratio of DDE and DDD to DDT has increased in soils, sediments, and biota (USEPA 2017). However, some recent studies report higher concentrations of DDT relative to its breakdown products in sediments and soils (Johnson et al. 1988, Pham et al. 1993, Muir et al. 1995, Bailey et al. 2005, Hu et al. 2010). The persistence of DDT and its breakdown products makes the pesticide a long-term threat to aquatic life.

The aim of this study is to better understand the fate and impact of DDT from a watershed and geosystems perspective, including transportation pathways of DDT residues from soils to aquatic sediments to aquatic life via an array of processes. System-wide effects of DDT in watersheds develop as geologic weathering and erosion processes interact to mobilize DDT-laden sediments. Chemical interactions of DDT with environmental parameters determine persistence and the dominant breakdown products. Hydrologic processes determine rates and forms of DDT-laden sediment transport, in runoff and stream load, and sediment deposition in flood plains, ponded areas, deltas and, eventually, lake basins or other sediment traps. Biological processes determine both the bioavailability and bioaccumulation of DDT residues, while biomagnification determines the toxicity impacts in the aquatic food chain. So, although DDT has ultimate impacts on ecosystems, the pathways for introduction to the ecosystem begin with geosystem and sedimentary processes. This holistic approach guides the objectives of this study, which are to: 1) identify source(s) of DDT residues in an affected watershed; 2) determine the duration and triggers for mobilization of the contaminant; and 3) determine if biomagnification is distinguishable on a sub-watershed scale.

\section{Study area}

Squam Lake, New Hampshire (NH), U.S., located at $43.76^{\circ},-71.53^{\circ}$ within the Merrimac River Watershed, is oligotrophic, and morphologically complex with 30 named islands and 16 basins, and a maximum depth of 30 meters (Figure 1). Prevailing winds and currents transport surface waters northeast to southwest, through a channel into Little Squam Lake, with outflows to the Squam River and, eventually, the Pemigewasset and Merrimac rivers. Bennett Brook is a second order tributary to Squam Lake. Its $2.6 \mathrm{~km}^{2}$ watershed comprises $2 \%$ of the $172 \mathrm{~km}^{2}$ Squam Lake watershed. Mean annual precipitation, snowfall, and temperature are $109 \mathrm{~cm}, 218 \mathrm{~cm}$, and $6{ }^{\circ} \mathrm{C}$, respectively (USGS 2016). The dominant soil is Rumney fine sandy loam, which is $71 \%$ sand, $22 \%$ silt, and $7 \%$ clay. The entire Squam Lake area was heavily glaciated until about 13,000 years ago. Poorly sorted glacial drift forms the parent material of most of the soils, 
overlying early Devonian Winnipesaukee Tonalite of the Squam Lake basin and the Kinsman Granodiorite and metasedimentary rocks of the surrounding highlands in the Squam Range (Lyons et al. 1997).

In 2017, a high concentration of DDT residues $(60 \mu \mathrm{g} / \mathrm{kg})$ was reported in a sediment sample collected in 2016 at the mouth of Bennett Brook, on the northwest end of Squam Lake (Vogel 2019). Within this watershed, a $0.25 \mathrm{~km}^{2}$ orchard of 2300 apple trees surrounding Bennett Brook was actively managed from the early 1920s until 1961, at the latest. Commercial agriculture has not occurred on those lands since, so it has been almost 60 years since the last likely DDT application, making the maximum duration of applications 15 years, based on the first availability of DDT in the U.S. around 1946. In the U.S., DDT use on orchards was common especially to control codling moth (Glass and Fiori 1955, Marshall 1959). Today, remnants of the orchard operation include two dump sites and a barn site. The barn was destroyed in a controlled burn around 1967 and, based on site observations today, the area was likely bulldozed afterwards, disrupting the foundation.

\section{Methods}

\section{Soil and sediment collection}

Historic data on land uses and watershed characteristics guided strategic selection of sampling locations to determine DDT source area(s) (Figure 1). Surficial sediments were collected from the upper few centimeters of Bennet Brook's streambed deposits by scooping the material directly into new, clean, borosilicate glass jars. Outside the stream channel, a stainless-steel probe was used to collect the upper few centimeters of 0 and $A$ soil horizons, dropped directly into sample jars. Samples were refrigerated until processing, then air dried for 48 hours and passed through a $250 \mu \mathrm{m}$ sieve, retaining the finer fraction.

Samples were processed largely following U.S. EPA method 3546, using a microwave digestor (CEM MARS 5), $14 \mathrm{~mL}$ vessels, and $1.25 \mathrm{~g}$ of sample mixed with $10 \mathrm{~mL}$ acetone/hexane (50/50 v/v) extraction solvent in each vessel. During extraction, the vessels were heated to $120^{\circ} \mathrm{C}$ in $10 \mathrm{minutes}$, followed by a 20 minute hold time and 15 minute cooling time. Because the vessels were smaller than the desired sample size, each sample was split across three vessels for extraction and recombined for analysis. For each sample, the liquid extract was collected and combined by passing the contents of the three vessels through a glass column with a fritted disc. Afterwards the samples were dried through a column with sodium sulfate, concentrated in a Kuderna-Danish (K-D) concentrator, and cleaned with florisil $(1 \mathrm{~g}, 6 \mathrm{~mL})$.

\section{Lake core collection}

Lake deposits can preserve the chronological sequence of sediments (Last and Smol 2001) and lake sediment cores, which collect a top to bottom column of sediment, can improve understanding of historical and current levels of DDT residues in lakes (Oliver et al. 1989, Muir et al. 1995, Olsson et al. 2000, Hu et al. 2010, Kurek et al. 2019). Analyses of Squam Lake sediment cores, therefore, provides insight for: 1) the duration of Bennett Brook sourcing DDT to the lake; 2 ) the historic and current levels the aquatic ecosystem has been and is exposed to; 3 ) the dominant DDT products in the lake, and; 4) triggers for mobilization from the Bennett Brook watershed to Squam Lake.

Freeze cores preserve the very top, highly flocculent, layers of sediments usually disturbed and sometimes lost by traditional corers. Freeze cores were collected from Squam Lake, proximal to the outflow of Bennett Brook, to obtain sediments sourced from the Bennett Brook sub-watershed (Figure 1). In conjunction with ground penetrating radar (GPR), which creates images of subsurface deposits, suitable coring locations beyond the littoral slope zone with undisturbed, layered sediments were identified. Using data from three, $130 \mathrm{~m}$-long GPR transects, radiating away from the mouth of Bennett Brook and established over the ice surface in 2019, three side-by-side freeze cores were collected. All were taken from the ice surface in February and March of 2019 , from 10-12 meters water depth. Frozen cores were subsampled using a band saw, with cuts at 1-cm intervals, and each sample surface was scraped with a clean razor blade before thawing. Samples from SQ2019-2 (41 cm length, 43.774750, -71.548517) were dried, homogenized and analyzed for ${ }^{210} \mathrm{~Pb}$, ${ }^{214} \mathrm{~Pb}$ and ${ }^{137} \mathrm{Cs}$ on a germanium gamma detector at Woods Hole Oceanographic Institution. Unsupported (excess) ${ }^{210} \mathrm{~Pb}$ was calculated by subtracting ${ }^{214} \mathrm{~Pb}$ from ${ }^{210} \mathrm{~Pb}$. Samples from SQ2019-3 (56 cm length, 43.774867, -71.548450) analyzed for DDT residues.

\section{Crayfish collection}

Crayfish reside and feed in sediments and are an important part of an aquatic food chain that includes fish, loons, heron, mink, otter, and racoons as top predators. Crayfish accumulate DDT by direct ingestion of DDT-laden sediments or consuming prey with DDT in their fatty tissues (Schilderman et al. 1977). Prolonged contamination of crayfish stems from DDT persistence in soils and subsequent inputs to stream and lake sediments with soil erosion and mobilization (Dimond et al. 1968). Since crayfish reside in an area-bound region, their contaminant load represents conditions at the collection site and makes them a useful pollution indicator species (Schilderman et al. 1977).

Northern crayfish (Faxonius virilis) were collected using beef liver lures at three locations in 2019: 1) the mouth of Bennett Brook (43.77698167, -71.54922819); 2) a channel connecting Squam Lake to Little Squam Lake (43.73230127, -71.58728496); and 3) Mirror Lake, Woodstock, NH (43.94283783, -71.69436269) (Figure 1). Mirror Lake is a reference site, chosen for its proximity to Squam Lake and watershed with relatively low development. This study also includes extraction and analyses of six crayfish collected by the Loon Preservation Committee (LPC) in 2013 approximately $2.3 \mathrm{~km}$ and $1.9 \mathrm{~km}$ distant from the mouth of Bennett Brook (43.769722, -71.528611 and 43.758611, -71.545278 , respectively). The crayfish samples were processed following a variant of the Tsygankov and Boyarova (2015) methodology. Samples were extracted via Soxhlet extraction, rotary evaporated, purified with concentrated sulfuric acid, and dried through a column with sodium sulfate. Next, samples were rotary evaporated and reconstituted, then cleaned with florisil (1 $\mathrm{g}, 6 \mathrm{~mL})$. All samples were single crayfish, except one composite sample of three small crayfish (Table 3). 


\section{Analytic method and quantification}

Soil, sediment, and crayfish samples analyzed at Plymouth State University used a gas chromatography-electron capture detector (Agilent 7820a GC-ECD) instrument, with helium as the carrier gas and nitrogen as the makeup gas. Samples were injected into the capillary column DB-608 (30 $\mathrm{m} \times 0.25 \mathrm{~mm} I \mathrm{D} \times 0.25$ $\mu \mathrm{m}$ ) and a subsequent DB-1701P column of the same dimensions, to confirm presence of analytes and their respective concentrations. Two $\mu \mathrm{L}$ of sample was injected into one column at a time, with a 10:1 split for soil and sediment analysis and 5:1 for crayfish analysis. During the runs, temperatures of the detector and inlet were $280^{\circ} \mathrm{C}$ and $200^{\circ} \mathrm{C}$, respectively. The oven was held at $150^{\circ} \mathrm{C}$ for 0.5 minutes and heated to $270^{\circ} \mathrm{C}$ at a rate of $6{ }^{\circ} \mathrm{C} / \mathrm{min}$, then held at $270^{\circ} \mathrm{C}$ for 10 minutes.

Samples were quantified using an external standard calibration with a minimum of four standards per isomer: $p, p^{\prime}$ DDT, $p, p^{\prime} D D E$, and $p, p^{\prime}$ DDD, collectively referred to as $\Sigma D D T$. $\Sigma D D T$ is reported with molecular weight adjustment, expressed in terms of the parent compound, p,p' DDT (FAO 2016). Our reporting limit is equivalent to the concentration of the lowest calibration standard which is $7 \mu \mathrm{g} / \mathrm{kg}$ for soil and sediment samples, and $2 \mu \mathrm{g} / \mathrm{kg}$ for crayfish samples. Detections below these values are reported as below the reporting limit (BRL). Samples with no measurable detections are reported as non-detects (ND).

\section{Quality Control and Cleanup}

To confirm the absence of analytes in the solvent, a solvent blank was analyzed at the start and end of each batch of samples. Each analytical batch contained a split sample, with known amounts of p,p' DDT, p,p' DDE, and p,p' DDD added to one half before extraction. Based on this, extraction efficiencies for p,p' DDT, p,p' DDE, and p,p' DDD were $42.4 \%-159.7 \%, 52.6 \%-140.0 \%$, and $137.6 \%-189.9 \%$, respectively. This variability is probably caused by the heterogenous nature of the soil and sediment samples. Extraction efficiencies for p,p' DDD were always greater than 100\%, because of DDT degradation into DDD within the GC-ECD instrument. From the beginning of the analytical work, within-instrument degradation was observed, but only when DDT was present in the sample, such as with each spiked sample. Recommended solutions were followed to resolve these degradation issues, including addition of a clean-up step with florisil, a Restek Siltek guard column ( $5 \mathrm{~m} \times 0.25 \mathrm{~mm}$ ID), and ultra-inert liners. The guard column was inserted into the inlet, and the other end into a connector piece that joins it with the analytical column. After each run, 6 inches of the guard column was trimmed at the inlet end, and if necessary, a new ultra-inert liner was installed. DDT standards were placed as quality control checks throughout the sample sequence to monitor DDT degradation; these confirmed the added cleanup steps greatly reduced degradation, but did not entirely eliminate it. One soil sample was split with Alpha Analytical, a commercial environmental testing laboratory, and our lab resulted in $57 \%$ of p,p' DDT and $58 \%$ of p,p' DDE of the Alpha Analytical results.

\section{Results}

\section{Bennett Brook watershed soils and sediments}

The analyses reveal measurable amounts of p,p' DDT and p,p' DDE but not p,p' DDD, in soil and stream sediment samples from the Bennett Brook watershed (Figure 2, Table 2). While no stream sediments have more p,p' DDT than p,p' DDE, 75\% of soil samples with detections above the reporting limit have a preponderance of p,p' DDT. Of those samples, p,p' DDT:p,p' DDT + p,p' DDE, is from 0.57 to 0.74 . We also find that DDT residues are widely distributed within the relict apple orchard. For soil samples collected outside the apple orchard along NH RTE $113,90 \%$ contain no detectable DDT residues. Areas downgradient of dump sites and at tributary confluences, showed low or no detections of $\Sigma$ DDT.

Elevated p,p' DDE concentrations occur in a NH RTE 113 gulley receiving runoff from the northern orchard area (the upper orchard). Of special note, soil samples from material overlying a bulldozed barn foundation have low detections, but soil samples B42, B53, and B54 contain DDT residues up to $53 x$ higher than any other sample collected in the watershed (Figure 2). These high-value samples are from a location just 2 meters east and downgradient of the bulldozed barn foundation (the barn site). One half of B53 was analyzed at Alpha Analytical, a commercial environmental testing laboratory, whose results support our findings. The barn site values range from 165.1 to $723.2 \mu \mathrm{g} / \mathrm{kg} \mathrm{p,p'} \mathrm{DDT} \mathrm{and} 57.8$ to $721.1 \mu \mathrm{g} / \mathrm{kg}$ p,p' DDE, with averages of $336.5 \pm 264.3 \mu \mathrm{g} / \mathrm{kg}$ and $270.1 \pm 305.7 \mu \mathrm{g} / \mathrm{kg}$, respectively. $\sum$ DDT levels (FAO 2016) are 232.1 to $1527.0 \mu \mathrm{g} / \mathrm{kg}$ and average $637.5 \pm 604.4 \mu \mathrm{g} / \mathrm{kg}$. The barn site samples are significantly different from all other samples in the Bennett Brook watershed, based on a Mann-Whitney $U$ test $(W=406.00, p=0.006)$. A point source is a highly concentrated area of contamination, at an explicit location. We conclude that the barn site meets the criteria for a point source.

\section{Lake sediments}

Radiometric dating of the lake sediments with ${ }^{137} \mathrm{Cs}$ and ${ }^{210} \mathrm{~Pb}$ produced mixed results. The ${ }^{137} \mathrm{Cs}$ signal rose from a typical pre-1950's zero background to an atypical plateau instead of peaking in 1964 and declining until a low Chernobyl peak in 1989. Smearing of the two peaks is not uncommon in anoxic sediments, because cesium is mobilized in reducing conditions. The ${ }^{210} \mathrm{~Pb}$ results are more conclusive, showing a clear extinction tail in excess ${ }^{210} \mathrm{~Pb}$ activity. From these ${ }^{210} \mathrm{~Pb}$ dating results, we developed a sediment depth-age model for lake core SQ2019-2 that we also apply to SQ2019-3 based on the less-than-3 meter distance between the SQ2019-2 and SQ2019-3 core sites, and the identical sediment depths of two marker horizons in both cores.

Squam Lake core sediment samples contain only p,p' DDE and p,p' DDD (Figure 3). Residues appear in the lake sediments soon after DDT came into use in the U.S. At $16 \mathrm{~cm}$ core depth (A.D. 1951), we find p,p' DDD, and at $15 \mathrm{~cm}$ core depth (A.D. 1957), we find p,p' DDE. Below these depths, residues are not detected. Above $16 \mathrm{~cm}$, concentrations range from $7.7-42.3 \mu \mathrm{g} / \mathrm{kg}$ p,p' DDE and $10.8-101.0 \mu \mathrm{g} / \mathrm{kg}$ p,p' DDD. The p,p' DDD concentrations are consistently higher than p,p' DDE. After initial appearance, concentrations of both residues increase until A.D. 1982, after which p,p' DDD concentrations decrease, p,p' DDE concentrations continue to increase and, overall, DDDT levels decrease to the present (Figure 3). The DDT residue levels in Bennett Brook and Squam Lake sediments are comparable to those in recent studies for other locales (Table 1).

Page $4 / 13$ 


\section{Crayfish}

Crayfish results are shown in Table 3. Crayfish from Mirror Lake, the reference site, contain no detectable DDT residues. Crayfish from Bennett Brook have p, $\mathrm{p}^{\prime}$ DDE levels of 0.7 to $12.6 \mu \mathrm{g} / \mathrm{kg}$ wet weight (ww). Neither p,p' DDT or p,p' DDD were detected in the crayfish. Crayfish collected in Squam Lake, distant from Bennett Brook have p,p' DDE values from no detection to $1.7 \mu \mathrm{g} / \mathrm{kg} w w$, which is comparable to other crayfish collected and analyzed in 2013 from Squam Lake with p,p' DDE levels of $0.29-1.1 \mu \mathrm{g} / \mathrm{kg}$ ww (Loon Preservation Committee, unpublished data). The levels of p,p' DDE in Bennett Brook crayfish (mean = 5.03) are statistically different than the other Squam Lake crayfish we analyzed (mean $=0.83$ ), based on a 2 sample $t$-test $(d f=8, t=2.42, p=0.042$ ). Residues in samples that were below the reporting limit were assigned the lowest standard value of $2 \mu \mathrm{g} / \mathrm{kg}$ in the statistical analysis. Regression analyses reveal no relationship between carapace length and $p, p^{\prime}$ DDE levels $(d f=12, F=3.82, p=0.076)$.

\section{Discussion}

\section{Sources of DDT}

DDT residues in Bennett Brook sediments are likely from multiple sources. DDT applied to an area can remain in soil for years, which explains the presence of DDT residues throughout the orchard area. Thus, it is probable that the orchard, as a whole, serves as a nonpoint source of DDT to Bennett Brook and, eventually, to Squam Lake. Furthermore, DDT contamination is largely constrained to the orchard operation, since $90 \%$ of samples collected outside the orchard resulted in no detection of residues. Therefore, DDT residues detected in Bennett Brook are likely sourced from legacy contamination from past DDT use on the orchard (Gao et al. 2013).

Based on the high levels detected at the barn site, DDT may have been stored there during the orchard operation, resulting in a point source of the contaminant. Of the barn site samples, B42 has the highest levels of residues $(1,527.0 \mu \mathrm{g} / \mathrm{kg} \Sigma \mathrm{DDT})$ and was the deepest sample collected in the soil horizon $(0-6 \mathrm{~cm})$, suggesting residues may be concentrated in the A horizon, below the $O$ horizon. The vertical extent of the contamination is as yet unknown but could be determined by collecting successively deeper samples until detections diminish. However, due to low mobility of DDT and potentially low soil invertebrate activity, vertical movement may be limited (Boul et al. 1994, Dimond and Owen 1996, Kaste et al. 2007). Our study included only six samples in and around the barn. More intensive sampling of the site is needed to assess the spatial distribution and range of levels at the location.

Roadside gullies along NH RTE 113 in the study area carry runoff, including any DDT-laden sediments, directly into Bennett Brook. We find p,p' DDE in the gully samples along the stretch of NH RTE 113 that is immediately downgradient of the upper orchard area and upgradient from the barn site. This finding supports the idea that DDT is not just from a single point source at the barn but is also transported to Bennett Brook by runoff from DDT-treated soils. The upper orchard is steeply sloped and was recently logged. Steep slopes have higher runoff and greater potential for erosion, even without the soil destabilization caused by logging (Tang et al. 2014). Soils eroded from the upper orchard may be nonpoint sources of residues adsorbed to the soils from historic applications, perhaps even more so because of the soils vulnerability to erosion (Munn and Gruber 1997). Since samples were not collected from the soils within the upper orchard, we cannot rule out the possibility of additional point sources contributing to p,p' DDE in the gullies.

\section{Transportation potential}

The main peak in p,p' DDD and p,p' DDE concentrations in the lake core sediments in 1982, ten years after the U.S. ban, indicates retention of DDT-laden particles in the watershed soils or Bennett Brook, creating a lag in delivery of residues to Squam Lake (Muir et al. 1995, Kurek et al. 2019).

We hypothesized that watershed erosion events would produce spikes of DDDT in the lake sediments, as floods and other disturbances mobilize stream sediments into Squam Lake. However, the extreme events of the Mother's Day Storm in 2006 or Hurricane Irene in 2011, and the beaver ponds breach in the lower reaches of Bennett Brook in 2002, all fail to leave a distinct DDT signature in the lake core. Higher resolution subsampling, for instance at $0.25 \mathrm{~cm}$ intervals, may provide more information on impacts from individual storms. Nonetheless, since unstable soils are eroded and mobilized during events such as these, it is reasonable to assume that extreme events have and will continue to trigger mobilization of the contaminant. The destruction of the barn in a controlled burn in about 1967 destabilized soils on the barn floor and also, potentially, stored DDT, allowing them to mobilize from the barn and into Bennett Brook. Bulldozing around the barn's foundation, which occurred sometime after the building was burned, likely increased the mobilization and flux of DDT.

The lake core results show that DDT residues have consistently entered Squam Lake for several decades, from a seemingly constant source, or sources, in the Bennett Brook watershed. Weathered soils can release persistent contaminants for years after last application (Santschi et al. 2001, Hu et al. 2010, Bettinetti et al. 2016). Kaste et al. (2007) find that New England soils are not easily eroded and, for soil mobilization to occur, the source soils must be especially vulnerable to erosion, such as stream banks, logged land, and steep slopes. Transportation of erodible sources can occur even at low rain intensities if the soils are unstable. The constant supply observed in the lake core is likely transported from multiple sources, including erodible orchard soils, the barn site, at culverts and behind beaver structures, and perhaps another unidentified point source in the upper orchard.

High levels in the barn site samples ( $\max =1,527.0 \mu \mathrm{g} / \mathrm{kg} \Sigma \mathrm{DDT}$ ), but not in samples downgradient of the barn $(\mathrm{max}=34.8 \mu \mathrm{g} / \mathrm{kg} \Sigma \mathrm{DDT}$ ) $\mathrm{may}$ suggest stable DDT-laden soils at the barn site or a relatively slow transportation rate. However, as previously mentioned, more sampling around and downgradient of the barn is needed to better understand stability of the soils and transportation rates.

\section{Persistence}


Historically, when higher levels of DDT than DDE occur in soil, it serves as a possible indicator of illegal usage or dumping (Hitch and Day 1992). However, as recent use cannot be completely ruled out, we have no reason to suspect illegal DDT usage in the study area. Supporting this, another study investigating the cause of unusually high DDT:DDE in soils concluded the cause was slow conversion of old DDT, applied before the ban, to DDE (Hitch and Day 1992). Yang et al. (2013) and Sánchez-Osorio et al. (2017) find p,p' DDT as the dominant isomer in soil samples, and the latter study concluded the lack of microbial degradation of p,p' DDT might account for its dominance in some soil samples analyzed in the study.

The presence of higher concentrations of p,p' DDT than p,p' DDE at the barn and other soil samples, but not in Bennett Brook sediments, suggests that p,p' DDT is preserved while in the soils but degrades to p,p' DDE once it enters Bennett Brook. This is consistent with studies that indicate longer persistence in soils than in mobilized sediments (Johnson et al. 1988, Pham et al. 1993).

Slower degradation is expected in the cold climates of New Hampshire, which has an average temperature of $6^{\circ} \mathrm{C}$ (Pham et al. 1993, Dimond and Owen 1996, U.S. Geological Survey 2016). Flooding, even of short duration, reduces the persistence of DDT by increasing anaerobic microbial activity that break down DDT into DDD by reductive dechlorination (Boul et al. 1994). The preponderance of DDE in the watershed's soils, therefore, is indicative of aerobic conditions. Also, the soils at the barn site are dominantly sandy ( $53 \%$ sand, $41 \%$ silt, and $6 \%$ clay). Longer DDT half-lives are likely in sandy soils, because they drain water rapidly and have low water-holding capacities (Crowe and Smith 2007, National Cooperative Soil Survey 2019).

Lichtenstein (1971) shows that DDT is more persistent and stable in soils that are applied with high doses of the insecticide. Also, Pereira (1996) reports that a point source with high concentrations of DDT may resist degradation to a greater degree than a site with lower concentrations, or from nonpoint or diffuse sources. Degradation occurs more rapidly at some distance away from a point source, yielding higher DDE:DDT values further from the source, and vice versa at the point source (Pereira et al. 1996). This is because aerobic microbial activity is inhibited in the presence of high DDT levels. Also, because the insecticide eliminates soil-dwelling organisms, bioturbation and soil decomposition in these areas are minimized. Both effects result in longer persistence (Nash and Woolson 1967, Pereira et al. 1996). At the barn site, soil microbial activity could be readily compared with locations out of the zone of contamination, providing more insight on this idea of persistence.

Although p,p' DDT was not detected in the lake sediments, this is not surprising given the rapid degradation rate of DDT to DDD by reductive dechlorination under anaerobic conditions (Wedemeyer 1966, Miles and Harris 1973, Johnson et al. 1988, Pham et al. 1993, Pereira et al. 1996). Supporting this, we find DDD:DDE in the lake sediments are always greater than 1, indicating dominance of anaerobic conditions in the lake depositional environment (Zhang and Shan 2014, Ma et al. 2016). Other studies also report higher DDD than DDT and DDE in lake sediments, since anaerobic conditions are common in lake bottoms (Oliver et al. 1989, Muir et al. 1995, Kurek et al. 2019).

\section{Aquatic organisms}

Since crayfish only travel up to a few hundred meters, crayfish collected in Bennett Brook represent those that live in or just outside the brook (Byron and Wilson 2001, Craddock 2009). Therefore, p,p' DDE detected in Bennett Brook-residing crayfish likely derives from sources in the Bennett Brook watershed. Crayfish collected in Bennett Brook have significantly higher concentrations of p,p' DDE than crayfish collected elsewhere in Squam Lake, distant from the brook. Therefore, crayfish results show that DDT residues sourcing from the Bennett Brook watershed have entered the aquatic food chain, at levels significantly higher than distant from the brook. However, fish and piscivorous birds, such as loons, kingfishers, and bald eagles, are not confined to as small a range as crayfish. They can easily travel and ingest prey with differing contaminant levels, depending on their location in the lake. Any such predator, whose range includes Bennett Brook, could experience higher DDT bioaccumulation.

We hypothesized that DDE levels would increase with crayfish carapace length because larger, older crayfish accumulate residues over a longer interval than smaller, younger crayfish. Supporting this hypothesis, in fish, the accumulation of DDE is correlated with increasing age and fat content (Gutenmann et al. 1992, USDOI 1998). Statistical analyses revealed no relationship between crayfish size and DDE levels in the crayfish we analyzed. However, the range of sizes we tested may not have represented enough a range to see this effect.

Crayfish usually have higher DDE than DDT, because the aerobic DDT-laden sediments they reside in have degraded to DDE, and DDT also breaks down in their bodies (Dimond et al. 1968, Boul 1995). Prolonged crayfish contamination occurs through persistence of DDT residues in contributing soils, and residues in crayfish will accumulate as long as the watershed soils provide that input (Dimond et al. 1968). Results reveal that the Bennett Brook watershed continues to supply DDT-laden soils, and so we expect contamination in the crayfish and Squam Lake food chain for many more years. Even low levels in crayfish should not be overlooked, because of biomagnification (Dimond et al. 1968).

Most sediment samples analyzed from Bennett Brook and Squam Lake exceed sediment quality guidelines for the protection of aquatic life (CCME 2001). For example, p,p' DDD and p,p' DDE concentrations in the upper $5 \mathrm{~cm}$ of the lake sediments are five and six times higher, respectively, than their PELs (Probable Effects Level), above which adverse biological are expected to occur frequently (CCME 2001). Exceeding the PELs of DDT, DDE, and DDD at 4.77, 6.75, and $8.51 \mu \mathrm{g} / \mathrm{kg}$, respectively, means that the levels are potentially harmful to Squam Lake's ecosystem.

\section{Conclusion}

DDT usage in the U.S. spans about 27 years, but it was only used on the Bennett Brook area orchards for a maximum of 15 years. Although it has been almost 60 years since the last application, elevated LDDT is still detected in the Bennett Brook watershed soils, sediments, and crayfish and in Squam Lake sediments. In this study, we demonstrate that DDT residues are transported from watershed soils to stream and lake sediments and into the aquatic food chain (Figure 4). This watershed systems approach aids in understanding the extent of the contamination. 
The orchard is a significant source of DDT to Bennett Brook and Squam Lake. Past and present sources include erodible orchard soils serving as a nonpoint source, the barn site, at culverts, behind beaver structures, and perhaps other unidentified point sources. A preponderance of p,p' DDT in most soil samples but not in sediment samples, suggests degradation once transported into Bennett Brook and Squam Lake. Based on lake core results, Squam Lake's food chain has been exposed to DDT residues at potentially harmful levels to the ecosystem since 1951. DDT levels in the lake sediments have a decreasing trend from 1982 to the present. Crayfish results show that DDT residues sourcing from the Bennett Brook watershed have entered the aquatic food chain, at levels significantly higher than distant from the brook. Further research should be done to determine the constraints and mobilization potential of DDT contamination at the barn site, and to understand if Squam Lake's aquatic life is experiencing adverse effects from the contaminant.

Climate change models for New England predict an increase in the frequency of intense storms, and therefore an increase in runoff and soil erosion that might expose and release additional, relatively undegraded DDT (Nearing 2001). This study calls attention to possible ongoing threats of persistent chemicals like DDT, despite bans in use decades ago.

\section{Declarations}

Funding: Sigma Xi, Plymouth State University, Woods Hole Oceanographic Institute

Conflicts of interest/Competing interests: Not applicable

Availability of data and material: Available data: May A (2020) DDT contamination in Squam Lake, NH: A Watershed Approach. Thesis, Plymouth State University. (Also available at

https://www.researchgate.net/publication/350442076_Amanda_May_Master\%27s_Thesis_DDT_Contamination_in_Squam_Lake_NH_A_Watershed_Approach)

Available material: A duplicate frozen core is available for additional work by contacting Dr. Lisa Doner (ladoner@plymouth.edu) at Plymouth State University (17 High St, Plymouth, NH 03264).

Code availability: Not applicable

Ethics approval: Not applicable

Consent to participate: Not applicable

Consent for publication: Yes

Acknowledgements

This work was funded by a Sigma Xi Student Research Grant, a Plymouth State University (PSU) Student Research and Creativity (SRAC) Grant, a PSU Faculty Research and Creativity (FRAC) Grant, and a PSU Environmental Science and Policy program Student Travel and Research (STAR) award. A special thanks to Woods Hole Oceanographic Institute for analyzing the lake core for ${ }^{210} \mathrm{~Pb},{ }^{214} \mathrm{~Pb}$, and ${ }^{137} \mathrm{Cs}$ for free, to the University of New Hampshire for allowing us to use their Microwave Accelerated Reaction System 5 (MARS 5), and to the Loon Preservation Committee for sharing their crayfish data.

\section{References}

1. Ames PL (1966) DDT Residues in the Eggs of the Osprey in the North-Eastern United States and Their Relation to Nesting Success. Journal of applied Ecology 3:87-97

2. Andrews JT, Belt ST, Olafsdottir S, Massé G, Vare LL (2009) Sea ice and marine climate variability for NW Iceland/Denmark Strait over the last 2000 cal. yr BP. Holocene 19:775-784

3. Agency for Toxic Substances \& Disease Registry (ATSDR) (2002) Public health statement for DDT, DDE, and DDD. Agency for Toxic Substances \& Disease Registry, Atlanta, Georgia

4. Bettinetti R, Quadroni S, Boggio E, Galassi S (2016) Recent DDT and PCB contamination in the sediment and biota of the Como Bay (Lake Como, Italy). Science of the Total Environment 542:404-410

5. Boul HL (1995) DDT residues in the environment - A review with a New Zealand perspective. New Zealand Journal of Agricultural Research 38:257-277

6. Boul HL, Garnham ML, Hucker D, Baird D, Aislable J (1994) Influence of agricultural practices on the levels of DDT and its residues in soil. Environmental Science and Technology 28:1397-1402

7. Byron CJ, Wilson KA (2001) Rusty crayfish (Orconectes rusticus) movement within and between habitats in Trout Lake, Vilas County, Wisconsin. Journal of the North American Benthological Society 20(4):606-614

8. Canadian Council of Ministers of the Environment (CCME) (2001) Canadian sediment quality guidelines for the protection of aquatic life. Canadian Council of Ministers of the Environment, Winnipeg, MB, Canada

9. Craddock CL (2009) Should I stay or should I go? The influence of habitat quality on movement patterns in Northern crayfish (Orconectes virilis). Dissertation, University of Arizona.

10. Crowe AS, Smith JE (2007) Distribution and persistence of DDT in soil at a sand dune-marsh environment: Point Pelee, Ontario, Canada. Canadian Journal of Soil Science 87:315-327 
11. Das S, Aria A, Cheng J, Souissi S, Hwang J, Ko F (2020) Occurrence and distribution of anthropogenic persistent organic pollutants in coastal sediments and mud shrimps from the wetland of central Taiwan. PloS one 15:1-17

12. Dimond JB, Kadunce RE, Getchell AS, Blease JA (1968) Persistence of DDT in crayfish in a natural environment. Ecology 49:759-762

13. Dimond JB, Owen RB (1996) Long-term residue of DDT compounds in forest soils in Maine. Environmental Pollution 92:227-230

14. Food and Agriculture Organization (FAO) (2016) Submission and evaluation of pesticide residues data for the estimation of maximum residues in food and feed. 3rd edn. Food and Agriculture Organization of the United Nations, Rome, Italy

15. Feingold BJ, Benoit G (2018) A novel method to infer historical DDT use on Cape Cod, Massachusetts (USA), based on $\Sigma$ DDT degradation and 210Pb dating in lake sediment cores. Journal of Paleolimnology 60:461-472

16. Gao J, Zhou H, Pan G, Wang J, Chen B (2013) Factors influencing the persistence of organochlorine pesticides in surface soil from the region around the Hongze Lake, China. Science of the Total Environment 443:7-13

17. Glass EH, B Fiori (1955) Codling moth resistance to DDT in New York. Journal of Economic Entomology 48:598-599

18. Gutenmann WH, Ebel JG, Kuntz HT, Yourstone KS, Lisk DJ (1992) Residues of p,p'-DDE and mercury in lake trout as a function of age. Archives of Environmental Contamination and Toxicology 22:452-455

19. Hitch RK, Day HR (1992) Unusual persistence of DDT in some Western USA soils. Bulletin of Environmental Contamination and Toxicology 48:259-264

20. Hu W, Wang T, Khim JS, Luo W, Jiao W, Lu Y, Naile JE, Chen C, Zhang X, Giesy JP (2010) HCH and DDT in sediments from marine and adjacent riverine areas of North Bohai Sea, China. Archives of Environmental Contamination and Toxicology 59:71-79

21. Johnson A, Norton D, Yake B (1988) Persistence of DDT in the Yakima River drainage, Washington. Archives of Environmental Contamination and Toxicology 17:289-297

22. Kang L, He Q, He W, Kong X, Liu W, Wu W, Li Y, Lan X, Xu F (2016) Current status and historical variations of DDT-related contaminants in the sediments of Lake Chaohu in China and their influencing factors. Environmental Pollution 219:883-896

23. Kaste JM, Heimsath AM, Bostick BC (2007) Short-term soil mixing quantified with fallout radionuclides. Geology 35:243-246

24. Khuman SN, Bharat G, Chakraborty P (2019) Spatial distribution and sources of pesticidal persistent organic pollutants in the Hooghly riverine sediment. Environmental Science and Pollution Research 27(4):4137-4147

25. Kurek J, MacKeigan PW, Veinot S, Mercer A, Kidd KA (2019) Ecological legacy of DDT archived in lake sediments from eastern Canada. Environmental Science \& Technology 53:7316-7325

26. Last WM, Smol JP (2001) An introduction to basin analysis, coring, and chronological techniques used in paleolimnology. In: Last WM, Smol JP (eds) Tracking environmental change using lake sediments: Basin analysis, coring, and chronological techniques. Springer Netherlands, Dordrecht, pp 1-5

27. Leatherman M (1997) Environmental effects: DDT. University of Delaware. http://www1.udel.edu/chem/C465/senior/fall97/insecticide/environ.html. Accessed March 62021

28. Lichtenstein EP, Fuhremann TW, Schulz KR (1971) Persistence and vertical distribution of DDT, lindane, and aldrin residues, 10 and 15 years after a single soil application. Journal of Agricultural and Food Chemistry 19:718-721

29. Lyons JB, Bothner WA, Moench RH, Thompson Jr JB (1997) Bedrock Geologic Map of New Hampshire. United States Geological Survey

30. Ma J, Pan L, Yang X, Liu X, Tao S, Zhao L, Qin X, Sun Z, Hou H, Zhou Y (2016) DDT, DDD, and DDE in soil of Xiangfen County, China: Residues, sources, spatial distribution, and health risks. Chemosphere 163:578-583

31. Marshall J (1959) Resistance to DDT in the codling moth in British Columbia. Entomological Society of British Columbia 56:59-63

32. Miles JRW, Harris CR (1973) Pesticides in water: organochlorine insecticide residues in streams draining agricultural, urban-agricultural, and resort areas of Ontario, Canada - 1971. Pesticides Monitoring Journal 6:363-368

33. Muir DCG, Grift NP, Lockhart WL, Wilkinson P, Billeck BN, Brunskill GJ (1995) Spatial trends and historical profiles of organochlorine pesticides in Arctic lake sediments. Science of the Total Environment 160-161:447-457

34. Munn MD, SJ Gruber (1997) The relationship between land use and organochlorine compounds in streambed sediment and fish in the central Columbia plateau, Washington and Idaho, USA. Environmental Toxicology 16:1877-1887

35. Nash RG, Woolson EA (1967) Persistence of Chlorinated Hydrocarbon Insecticides in Soils. Science 157:924-927

36. National Cooperative Soil Survey. National Cooperative Soil Characterization Database.

https://websoilsurvey.sc.egov.usda.gov/App/WebSoilSurvey.aspx. Accessed September 162019

37. Nearing MA (2001) Potential changes in rainfall erosivity in the U.S. with climate change during the 21 st century. Journal of Soil and Water Conservation $56: 229-232$

38. Nygård T (1983) Nordic society oikos pesticide residues and shell thinning in eggs of peregrines in Norway. Ornis Scandinavia 14:161-166

39. Oliver BG, Charlton MN, Durham RW (1989) Distribution, redistribution, and geochronology of polychlorinated biphenyl congeners and other chlorinated hydrocarbons in Lake Ontario sediments. Environmental Science \& Technology 23:200-208

40. Olsson M, Bignert A, Eckhéll J, Jonsson P (2000) Comparison of temporal trends (1940s-1990s) of DDT and PCB in Baltic sediment and biota in relation to eutrophication. Royal Swedish Academy of Sciences 29:195-201

41. Pereira WE, Hostettler FD, Rapp JB (1996) Distributions and fate of chlorinated pesticides, biomarkers and polycyclic aromatic hydrocarbons in sediments along a contamination gradient from a point-source in San Francisco Bay, California. Marine Environmental Research 41:299-314

42. Pham T, Lure K, Lemieux C (1993) The occurrence, distribution and sources of DDT in the St. Lawrence River, Quebec (Canada). Chemosphere 26:15951606

Page $8 / 13$ 
43. Quensen JFI, Mueller SA, Jain MK, Tiedje JM (1998) Reductive dechlorination of DDE to DDMU in marine sediment microorganisms. Science 280:722724

44. Ricking M, Schwarzbauer J (2012) DDT isomers and metabolites in the environment: An overview. Environmental Chemistry Letters 10:317-323

45. Rissato SR, Galhiane MS, Ximenes VF, de Andrade RMB, Talamoni JLB, Libânio M, de Almeida MV, Apon BM, Cavalari AA (2006) Organochlorine pesticides and polychlorinated biphenyls in soil and water samples in the Northeastern part of São Paulo State, Brazil. Chemosphere 65:1949-1958

46. Sánchez-Osorio JL, Macías-Zamora JV, Ramírez-Álvarez N, Bidleman TF (2017) Organochlorine pesticides in residential soils and sediments within two main agricultural areas of northwest Mexico: Concentrations, enantiomer compositions and potential sources. Chemosphere 173:275-287

47. Santschi PH, Presley BJ, Wade TL, Garcria-Romero B, Baskaran M (2001) Historical contamination of PAHs, PCBs, DDTs, and heavy metals in Mississippi River Delta, Galveston Bay and Tampa Bay sediment cores. Marine Environmental Research 52:51-79

48. Schilderman PAEL, Moonen EJC, Mass LM, Welle I, Kleinjans JCS (1977) Use of crayfish in biomonitoring studies of environmental pollution of the river Meuse. Ecotoxicology and Environmental Safety 44:241-252

49. Tang XY, Zhang XB, Guan Z, Long Y, Tang Q, Lü YJ (2014) Historical sediment record of $137 \mathrm{Cs}$, $\delta$-HCH, and $\delta 13 \mathrm{C}$ reflects the impact of land use on soil erosion. Journal of Mountain Science 11:866-874

50. Tsygankov VY, Boyarova MD (2015) Sample preparation method for the determination of organochlorine pesticides in aquatic organisms by gas chromatography. Achievements in the Life Sciences 9:65-68

51. United States Department of the Interior (USDOI) (1998) Guidelines for interpretation of the biological effects of selected constituents in biota, water, and sediment. United States Environmental Protection, Washington, D.C.

52. United States Environmental Protection Agency (USEPA) (1975) DDT: A review of scientific and economic aspects of the decision to ban its use as a pesticide. United States Environmental Protection, Washington, D.C.

53. United States Environmental Protection Agency (USEPA) (2017) DDT - A brief history and status. United States Environmental Protection Agency, Washington, D.C.

54. United States Geological Survey (USGS) (2016) The StreamStats Program. http://streamstats.usgs.gov. United States Geological Survey, Reston, VA

55. Vogel H (2010) The Squam Lake loon initiative: Progress report September 2010. https://www.nuttallclub.org/wp-content/uploads/2017/01/SquamLake-Loon-Initiative.pdf. Accessed March 62021

56. Vogel H (2019) The Squam Lake loon initiative: Progress report November 2019. https://loon.org/wp-content/uploads/2020/01/2019-November-SLLIreport.pdf. Accessed March 62021

57. Wedemeyer G (1966) Dechlorination of DDT by Aerobacter aerogenes. Science 152:647

58. Wohl E (2015) Legacy effects on sediments in river corridors. Earth-Science Reviews 147:30-53

59. Yang D, Qi S, Zhang J, Wu C, Xing X (2013) Organochlorine pesticides in soil, water and sediment along the Jinjiang River mainstream to Quanzhou Bay, southeast China. Ecotoxicology and Environmental Safety 89:59-65

60. Zhang H, Shan B (2014) Historical distribution of DDT residues in pond sediments in an intensive agricultural watershed in the Yangtze-Huaihe region, China. Journal of Soils and Sediments 14:980-990

\section{Tables}

Table 1 Comparison of $\Sigma D D T(\mu \mathrm{g} / \mathrm{kg})$ levels in sediments in recent studies

\begin{tabular}{|lll|}
\hline Location & EDDT $(\mu \mathrm{g} / \mathrm{kg})$ & Reference \\
\hline Squam Lake, New Hampshire & $\mathrm{ND}-152.02$ & This study \\
\hline Changhua County, Taiwan & $0.03-2.63$ & Das et al. 2020 \\
\hline Hooghly River, India & $0.46-41.2$ & Khuman et al. 2019 \\
\hline Pine River, Michigan & $7.9-154.1$ & Harwood et al. 2019 \\
\hline Southern California & ND -257 & Kivenson et al. 2019 \\
\hline China & $0.033-4140.07$ & Lv et al. 2019 \\
\hline Cape Cod, Massachusetts & ND -119 & Feingold and Benoit 2018 \\
\hline Lake Como, Italy & $50-63$ & Bettinetti et al. 2016 \\
\hline Lake Chaohu, China & $0.31-25.41$ & Kang et al. 2016 \\
\hline Quanzhou Bay, China & $0.21-7.83$ & Yang et al. 2013 \\
\hline North Bohai Sea, China & $<$ LOD -86.46 & Hu et al. 2010 \\
\hline Northwest Mexico & $0.21-55.0$ & Sánchez-Osorio 2017 \\
\hline
\end{tabular}

ND No Detection; LOD Limits of Detection 
Table 2: Summary data for Bennett Brook DDT isomer analyses

\begin{tabular}{|llll|}
\hline Sample Type & \multicolumn{1}{l}{ p,p' DDT } & p,p' DDE & p,p' DDD \\
\cline { 2 - 4 } & Range (average \pm standard deviation $) \mu \mathrm{g} / \mathrm{kg}$ & \\
\hline Bennett Brook stream sediments $(\mathrm{n}=18)$ & $\mathrm{ND}-6.8(1.5 \pm 2.1)$ & $\mathrm{ND}-37.9(13.2 \pm 10.2)$ & ND \\
\hline Bennett Brook watershed soils $(\mathrm{n}=25)$ & $\mathrm{ND}-723.2(58.2 \pm 155.4)$ & $\mathrm{ND}-721.1(46.5 \pm 147.0)$ & $\mathrm{ND}$ \\
\hline
\end{tabular}

$n$ number of samples; ND No Detection

Table 3 p,p' DDE ( $\mu \mathrm{g} / \mathrm{kg}$ wet weight) concentrations in crayfish collected in Bennett Brook and in Squam Lake

\begin{tabular}{|c|c|c|c|}
\hline Location & Sample ID & Carapace Length (mm) & $p, p^{\prime} D D E(\mu g / k g$ wet weight) \\
\hline \multirow[t]{9}{*}{ Bennett Brook } & $\mathrm{BC} 1$ & 44 & 12.5 \\
\hline & $\mathrm{BC} 2$ & 40 & 2.3 \\
\hline & $\mathrm{BC} 3$ & 44 & 10.3 \\
\hline & BC4 & $36^{*}$ & 2.4 \\
\hline & BC5-1 & 33 & 1.2 \\
\hline & BC6-1 & 18 & 12.6 \\
\hline & BC7-1 & 34 & 0.7 \\
\hline & BC7-2 & 25 & 2.5 \\
\hline & BC7-3 & 38 & 0.8 \\
\hline \multirow[t]{10}{*}{ Squam Lake } & SC1-1 & 37 & 0.6 \\
\hline & SC2-1 & 35 & ND \\
\hline & SC2-2 & 30 & BRL \\
\hline & $\mathrm{SC} 2-3$ & 32 & 0.8 \\
\hline & MPC1 & 34 & ND \\
\hline & MPC2 & 23 & ND \\
\hline & MPC3 & 35 & 1.1 \\
\hline & FFC1 & 35 & 0.9 \\
\hline & FFC2 & 36 & 1.2 \\
\hline & FFC3 & 30 & 1.7 \\
\hline
\end{tabular}

ND No Detection. * denotes average carapace length (composite sample of three crayfish)

\section{Figures}




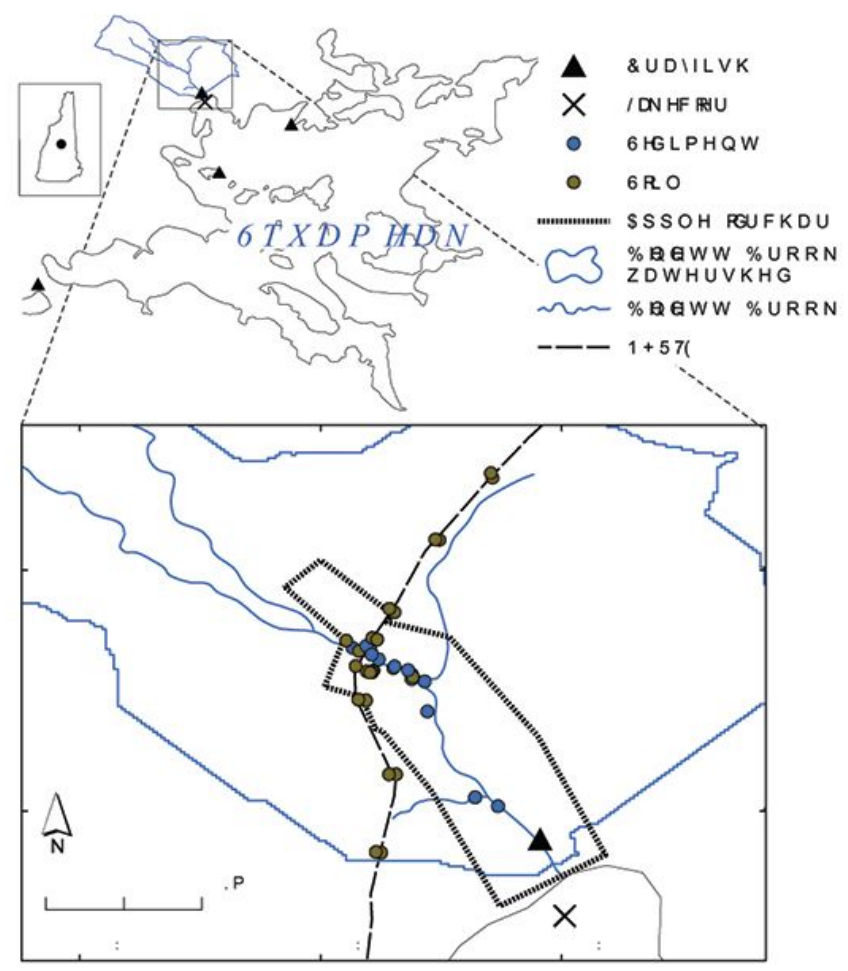

\section{Figure 1}

Study area located in central New Hampshire, U.S. and sampling locations for crayfish, soils, sediments, and lake cores Note: The designations employed and the presentation of the material on this map do not imply the expression of any opinion whatsoever on the part of Research Square concerning the legal status of any country, territory, city or area or of its authorities, or concerning the delimitation of its frontiers or boundaries. This map has been provided by the authors. 


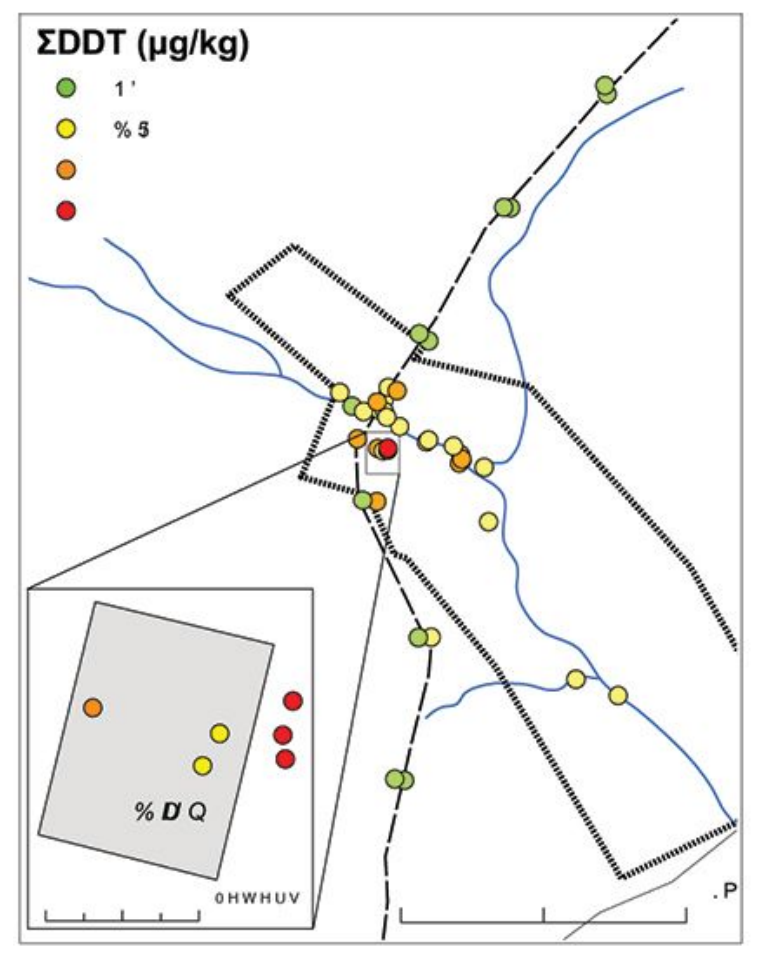

\section{Figure 2}

¿DDT levels in sediment and soil samples within the Bennett Brook watershed. Only p,p' DDT and p,p' DDE were detected in the samples analyzed by PSU. The red dots, or the highest concentrations, are at the barn site. ND No Detection; BRL Below Reporting Limit Note: The designations employed and the presentation of the material on this map do not imply the expression of any opinion whatsoever on the part of Research Square concerning the legal status of any country, territory, city or area or of its authorities, or concerning the delimitation of its frontiers or boundaries. This map has been provided by the authors.

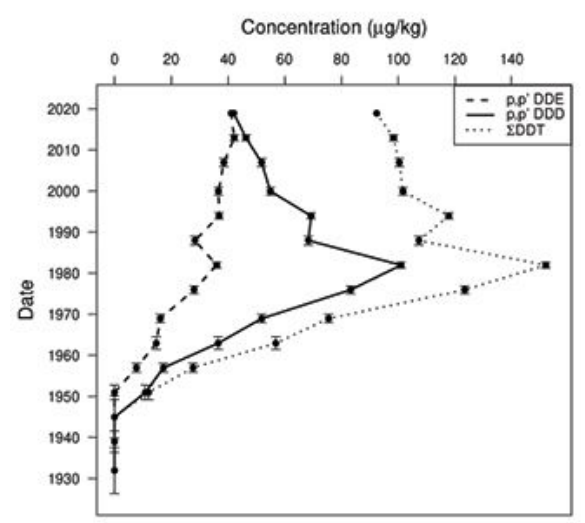

\section{Figure 3}

p,p' DDE, p,p' DDD, and $\Sigma$ DDT concentrations from the lake core SQ2019-3. The vertical bars represent the 210Pb error 


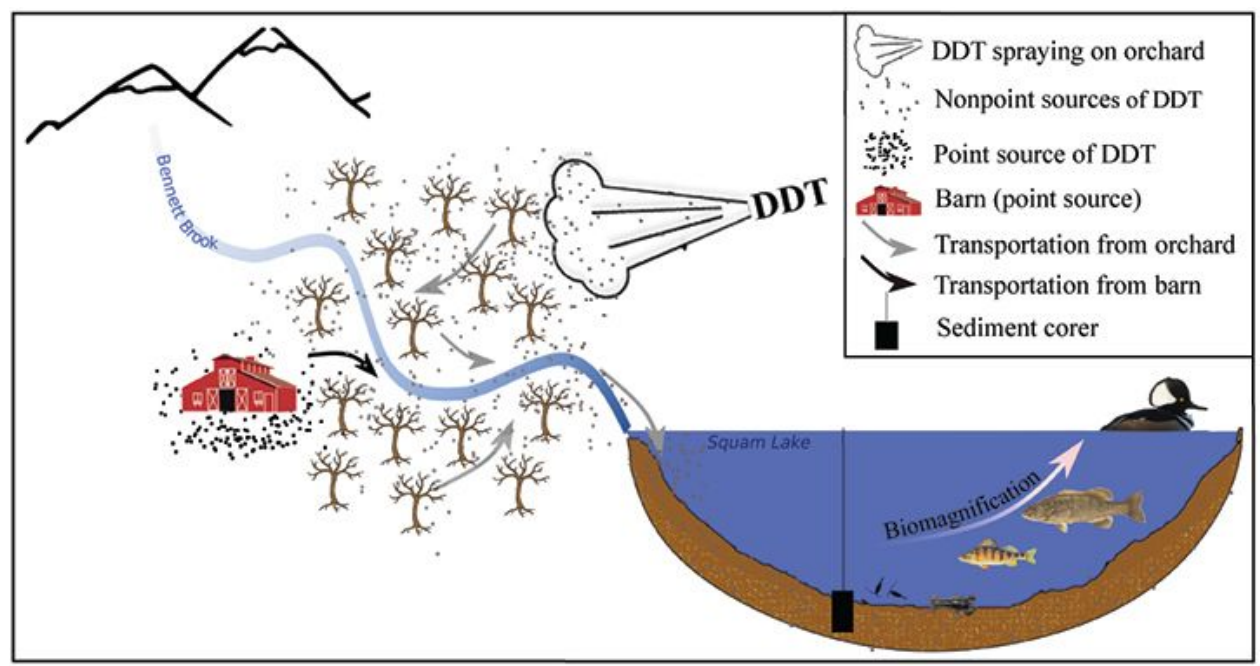

Figure 4

Conceptual diagram of transportation pathways of DDT residues from the Bennett Brook watershed to Squam Lake 